\title{
Influence of Surface Characteristics of Different Implant Abutment Materials on Growth of Porphyromonas Gingivalis
}

\author{
Julius MAMINSKAS ${ }^{1}{ }^{*}$, Monika ZALECKYTE ${ }^{1}$, Jurgis PILIPAVICIUS ${ }^{2}$, \\ Tadas VENSKUTONIS ${ }^{3}$, Marco CICCIU $^{4}$, Gintaras JUODZBALYS $^{5}$
}

\author{
${ }^{1}$ Department of Prosthodontics, Lithuanian University of Health Sciences, Kaunas 50106, Lithuania \\ ${ }^{2}$ Department of Electrochemical Material Science Center for Physical Sciences and Technology (FTMC), Vilnius, \\ Lithuania; Faculty of Chemistry and Geosciences, Vilnius University, Vilnius 10257, Lithuania \\ ${ }^{3}$ Department of Dental and Oral Pathology, Lithuanian University of Health Sciences, Kaunas 50140, Lithuania \\ ${ }^{4}$ Department of Biomedical and Dental Sciences and Morphological and Functional Imaging, Messina University, 98100 \\ Messina, Italy \\ ${ }^{5}$ Department of Maxillofacial Surgery, Lithuanian University of Health Sciences, Kaunas 50140, Lithuania \\ crossref http://dx.doi.org/10.5755/j02.ms.25601
}

Received 31 March 2020; accepted 18 June 2020

\begin{abstract}
The purpose of the present study was to determine the surface physicochemical properties of polished implant abutment materials and to investigate their relationship with the growth of Porphyromonas gingivalis in vitro. Four groups of the most popular prosthetic materials were used in this study: titanium alloy (Ti), yttria-stabilized zirconium oxide (3Y-TZP), polyether ether ketone (PEEK) composite, and poly(methyl methacrylate) (PMMA). The plate shape specimens $(10 \times 10 \times 0.5 \mathrm{~mm})$ were polished by applying sequential mechanical polishing. Measurements of water contact angle (WCA), surface free energy (SFE) and roughness were performed. Also, the growth of P.gingivalis was measured via counting colony-forming units to milliliter $(\mathrm{CFUs} / \mathrm{mL})$. The WCA means were significantly different among all groups, and the highest hydrophilicity was observed on the PEEK, whereas the lowest on PMMA surface. All measured surfaces had similarly low SFE values, but Ti, 3Y-TZP, and PEEK demonstrated more expressed polar parts. All means of roughness were beyond the micro-level and were lower than $0.2 \mu \mathrm{m}$. The highest CFUs/mL was assessed on the PMMA and it was significantly different from others, whereas the lowest was on 3Y-TZP. The surface roughness had a significant impact on CFUs/mL growth.
\end{abstract}

Keywords: abutment, biofilms, roughness, peri-implantitis, Porphyromonas Gingivalis, surface.

\section{INTRODUCTION}

A dental implant has two functional parts: the root and the coronary prosthetic part, and they differ in their properties. The root part is in direct contact with bone and essential for ingrown osteoblasts and successful osseointegration [1-3]. It has to be rough because such a surface enhances osseointegration. For the purpose of increasing the surface area, during the manufacturing process, it can be sandblasted, acid-etched, or plasma sprayed, or a laser can be applied to it to achieve roughness and increase the surface area [4-6]. The prosthetic part starts from the bone level, crosses the mucosa, and acts as an abutment for a dental prosthesis. Therefore, it makes contact with gingival cells and oral microbiota [7].

According to the Human Oral Microbiome Database (HOMD) (http://www.homd.org/) [8], more than 700 different bacteria species may exist in the oral cavity and some of them are pathogens. The mucosal barrier typically seals the intraosseous dental implant during the healing process and while it is being used [9], but the conventional transmucosal dental implant generally acts as a bridge between an aseptic tissue area and the colonised oral cavity. Only a firm soft tissue sealing can protect the implant from oral microbiota [10].

\footnotetext{
* Corresponding author. Tel.: +370-60100033.

E-mail address: julius.maminskas@lsmuni.lt (J. Maminskas)
}

The surface of the prosthetic part has to be favorable for gingival cells [7, 11-13], but unfavorable for bacteria and resistant to plaque accumulation [7, 14, 15]. Many authors established that bacterial adhesion is related to the physicochemical properties of the material surface, such as hydrophilicity, surface free energy, and roughness [16, 17].

The peri-implant bone loss might be affected by overloading induced stress at supporting bone [18-21], but plaque-induced inflammation is the predominant factor $[22,23]$. Bacterial plaque induces fibroblast response, causing the inflammation of peri-implant soft tissue - periimplant mucositis [24, 25]. Because of the inflammation, the epithelial barrier is damaged; therefore, untreated periimplant mucositis eventually reaches the bone and progresses into peri-implantitis [26]. The specific/significant promoter, Porphyromonas gingivalis and the presence of it may accelerate the progression of the disease due to the expression of several virulence factors [27-29]. Also, the amount of this pathogen in dental biofilm is associated with the contributing factors of Alzheimer's disease [30]. Thus, from a clinical perspective, it is desirable to avoid bacterial plaque formation around dental implants.

From the biological point of view, the choice of abutment materials, as well as the improvement of their surface physicochemical properties, might be essential for the peri-implant soft tissue health. Unfortunately, no clear evidence-based guidelines related to these choices across 
databases was found. Still, by changing surface properties, the possibilities of bacteria adhesion could be reduced and, at the same time, improved soft tissue sealing.

Polishing protocols of prosthetic materials are highly clinical relevant topics and various improvements are being suggested in the recent studies [31-33]. Across databases, various polishing strategies exist, but these have a lack of standardization. Mainly, commercially available rotary instruments are used for surface polishing in most of the present studies, but these have a lack of information about grain size and difficulties for establishing of identical conditions for all samples. For this study, an extended sequencing polishing strategy following ISO 6344:3 standards for abrasive materials was applied with a clearance of grinding materials and composition [34]. The present study aimed to determine the surface properties of different prosthetic materials, such as the water contact angle (WCA), surface free energy (SFE), and roughness, after sequential mechanical polishing and to investigate their relationship with the growth of $P$. Gingivalis in vitro.

\section{EXPERIMENTAL DETAILS}

\subsection{Specimens preparation}

According to the manufacturer's recommendations, the plate shaped samples $(10 \times 10 \times 0.5 \mathrm{~mm})$ were milled by using the computer-aided design and computer-aided manufacturing system (Dental Concept Systems DC1, Dental Concept Systems $\mathrm{GmbH}$ ) of four commercially available prosthetic materials (Table 1). In total, four groups were prepared ( $\mathrm{n}=10$ for each group): Ti, titanium alloy; 3Y-TZP, yttria-stabilized zirconium oxide; PEEK, polyether ether ketone composite; and PMMA, poly(methyl methacrylate). Samples of 3Y-TZP were additionally sintered in the furnace (Zubler Vario S400, Zubler USA) for two hours at $1450{ }^{\circ} \mathrm{C}$ temperature.

Table 1. Summary of used commercially available materials

\begin{tabular}{|c|c|c|}
\hline Groups & Materials & wt. $\%$ \\
\hline $\mathrm{Ti}$ & $\begin{array}{l}\text { Ti6Al4V, DC Titan 5, Dental } \\
\text { Concept Systems GmbH, } \\
\text { Ulm, Germany }\end{array}$ & $\begin{array}{l}\mathrm{Ti}-90 \% \\
\mathrm{Al}-6 \% \\
\mathrm{~V}-4 \%\end{array}$ \\
\hline 3Y-TZP & $\begin{array}{l}\mathrm{ZrO}_{2} 3 \mathrm{Y} \text {-TZP Nacera Pearl, } \\
\text { Doceram Medical Ceramics } \\
\text { GmbH, Dortmund, Germany }\end{array}$ & $\begin{array}{l}\mathrm{ZrO}_{2}-92.5 \% \\
\mathrm{Y}_{2} \mathrm{O}_{3}-5.5 \% \\
\mathrm{HfO}_{2}-1.9 \% \\
\text { Others-0.1\% }\end{array}$ \\
\hline PEEK & $\begin{array}{l}\text { BioHPP, Bredent GmbH, } \\
\text { Senden, Germany }\end{array}$ & $\begin{array}{l}\text { PEEK }-70 \% \\
\mathrm{TiO}_{2}-30 \%\end{array}$ \\
\hline PMMA & $\begin{array}{l}\text { Brecam Universal, Bredent } \\
\text { GmbH, Senden, Germany } \\
\end{array}$ & PMMA-100\% \\
\hline
\end{tabular}

\subsection{Surface treatment}

The surfaces were polished with the decreasing coarseness of water-resistant silicon carbide (SiC) abrasive paper P2000, P2500, P3000, P4000 (Starcke GmbH \& Co.) under water cooling/washing. The grain size of SiC abrasive materials described by ISO 6344:3 [34]. The polishing was completed with a diamond polishing paste and a natural brush (Zirkopol, Feguramed GmbH). The polishing cycle of each coarseness was performed using a rotary machine Holzmann metal lathe ED3000ECO
(Maschinenhandel Gronau Inh.) for 60 seconds at 3000 RPM.

\subsection{Contact angle and surface free energy}

The WCA and SFE were measured with an optical tensiometer (CAM 200, KSV Instruments Ltd). Bi-distilled water was used in a heavy phase for measurements. Before measurement, all substrates were cleaned via sonication in hexane and bi-distilled water, and then, they were dried in a vacuum oven at $50{ }^{\circ} \mathrm{C}$ for two hours. The measurements were performed at room temperature by placing a small drop $(4-7 \mu \mathrm{L})$ of a particular liquid on a tested substrate and measuring the WCA of the solvent droplet. The SFE was calculated by using the Owens-Wendt method [35], which provides the dispersive and polar components of a measured substrate's SFE.

\subsection{Surface roughness}

The roughness average $\left(R_{\mathrm{a}}\right)$ was measured in a contactless way by using the atomic force microscope (AFM) (Agilent 5500 AFM/SPM, Agilent Technologies). Three $0.25 \mu \mathrm{m}^{2}$ areas were randomly scanned for each specimen, and data of the surface topography and roughness were collected.

\subsection{Bacterial strain and culture media}

P. Gingivalis ATCC 33277 (Microbiologics) was the strain selected for this study. Following provider recommendations, the lyophilized bacteria were spread on Schaedler agar with vitamin $\mathrm{K}_{1}$ and $5 \%$ sheep blood (Acumedia) under anaerobic conditions (10\% $\mathrm{H}_{2}, 10 \%$ $\mathrm{CO}_{2}$, and $80 \% \mathrm{~N}_{2}$ ) at $35 \pm 1{ }^{\circ} \mathrm{C}$ for 48 hours.

\subsection{Bacterial formation}

All samples were washed with a $70 \%$ ethyl alcohol for 10 minutes, passively dried, packed in sterilization bags, and sterilized by autoclavation at $121^{\circ} \mathrm{C}$ for 39 minutes (Hygoclave 90, Dürr Dental). Each sample was placed in a separate sterile tube and inoculated with a 0.5 McFarland standard suspension, which corresponds to a concentration of $1.5 \cdot 10^{8}$ bacteria per $1 \mathrm{~mL}$. It was prepared from the sterile physiological saline and the two-day culture of bacteria. This suspension was supplemented with trypticase soy broth (Becton Dickinson and Company), hemin $(10 \mu \mathrm{g} / \mathrm{mL}$; Sigma Chemical Co.), and menadione ( $5 \mu \mathrm{g} / \mathrm{mL}$; Sigma Chemical Co.). The tubes were left in an aerostat for 48 hours $\left(10 \% \mathrm{H}_{2}, 10 \% \mathrm{CO}_{2}\right.$, and $\left.80 \% \mathrm{~N}_{2}\right)$ at $35 \pm 1{ }^{\circ} \mathrm{C}$ temperature. After cultivation, specimens were removed and transferred to other tubes with $1 \mathrm{~mL}$ phosphate-buffered saline (PBS) solution and $1 \%$ proteinase $\mathrm{K}(50 \mathrm{mg} / \mathrm{mL})$ (Sigma-Aldrich) to detach bacteria from surfaces chemically. Samples with proteinase $\mathrm{K}$ and PBS solutions were stored at $37^{\circ} \mathrm{C}$ for 60 minutes. Vortexing for one minute was also applied to increase the detachment of bacteria mechanically. The samples were removed from the medium, and the density of the slurries was measured with the McFarland Densitometer (Biosan). McFarland's numerical value was calculated according to the proportion of colony-forming units per milliliter (CFUs/mL). 


\subsection{Statistical analysis}

The data were analysed using GraphPad Prism 8 software package. The WCA, SFE, roughness and CFUs/mL measurements were analysed based on standard deviations and means. Variables were checked for Gaussian distribution based on D' Agostino-Pearson tests. Multiple comparisons of all measurements were performed among groups by using Anova analysis based on Tukey's tests of variance least significant difference. Also, regressions among measurements were checked. The significance level was 0.05 for all calculations.

\section{RESULTS}

\subsection{Water contact angle and surface free energy}

For the purpose of evaluating the wettability of surfaces, WCA and SFE measurements were performed (Fig. 1). The highest WCA values were observed on the PMMA substrate $\left(100.1^{\circ}\right)$ and the lowest on PEEK $\left(76.79^{\circ}\right)$, whereas $\mathrm{Ti}$ and 3Y-TZP demonstrated intermediate WCA means. A statistically significant difference at a significance level of $p<0.05$ was observed among all groups. According to these results of the WCA measurements, the PMMA surface was the most hydrophobic $(p<0.0001)$.

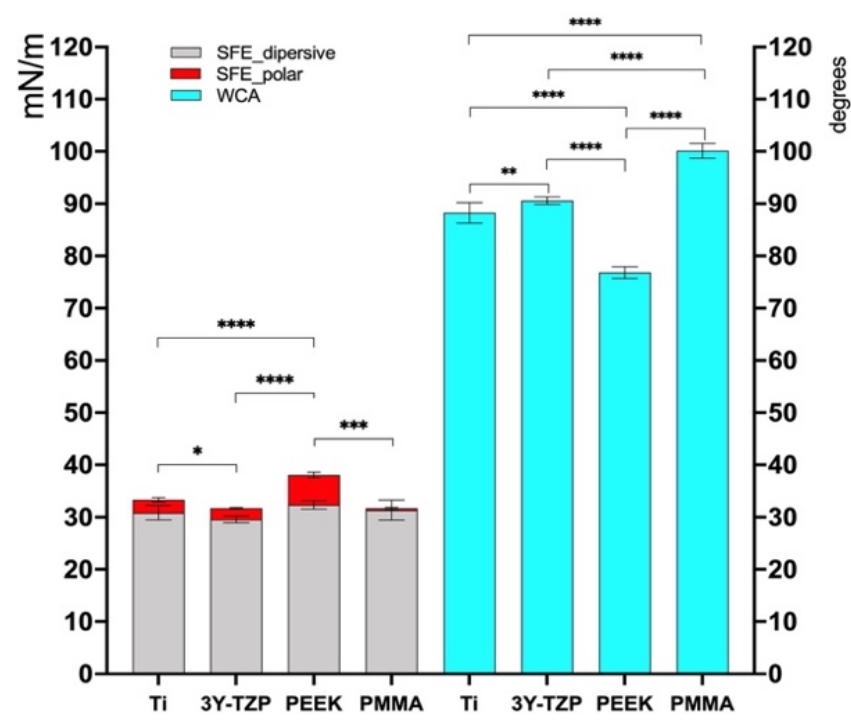

Fig. 1. SFE and WCA of samples ( $\mathrm{n}=10$ for each group): titanium alloy (Ti), yttria-stabilized zirconium oxide (3Y-TZP), polyether ether ketone composite (PEEK) and poly(metheyl methacrylate) (PMMA). Multiple comparisons by Tukey's test and significant difference at levels: ns $-p>0.05$ (non-marked groups), $*-p=0.0243$; $* *-p=0.0031, * * *-p=0.0003, * * * *-p<0.0001$

All measured surfaces had similarly low SFE_total means, and no difference was found between $3 \mathrm{Y}-\mathrm{TZP}$ and PMMA ( $p>0.9999)$. However, Ti, 3Y-TZP, and PEEK had more expressed polar parts. Differences in the SFE polar parts were detected among the polymeric materials, where the values were much higher on the PEEK surface $(5.71 \mathrm{mN} / \mathrm{m})$ than on the PMMA surface $(0.37 \mathrm{mN} / \mathrm{m})$ $(p<0.0001)$.

However, our finding did not confirm any relation following linear regression between the WCA and SFE means either their relations with roughness or CFUs/mL.

\subsection{Surface roughness}

The $R_{\mathrm{a}}$ parameter represented the surface roughness. All means of surface roughness were beyond the micro level and significantly different among each other $(p<0.0001)$ (Table 2). The highest roughness was detected for PMMA $R_{\mathrm{a}}=62.33 \mathrm{~nm}$, whereas the lowest was for 3YTZP $R_{\mathrm{a}}=9.36 \mathrm{~nm}$ (Fig. 2).

Table 2. Multiple comparisons of surface roughness among groups ( $\mathrm{n}=10$ for each) by Tukey's test and significant difference of means at level $* * * *-p<0.0001$

\begin{tabular}{|l|l|l|l|}
\hline Tukey's test & Mean 1 & Mean 2 & Diff. \\
\hline Ti vs. 3Y-TZP & 22.05 & 9.36 & $12.69 * * * *$ \\
\hline Ti vs. PEEK & 22.05 & 49.57 & $27.52 * * * *$ \\
\hline Ti vs. PMMA & 22.05 & 62.33 & $40.28 * * * *$ \\
\hline 3Y-TZP vs. PEEK & 9.36 & 49.57 & $40.21 * * * *$ \\
\hline 3Y-TZP vs. PMMA & 9.36 & 62.33 & $52.97 * * * *$ \\
\hline PEEK vs. PMMA & 49.57 & 62.33 & $12.76 * * * *$ \\
\hline
\end{tabular}

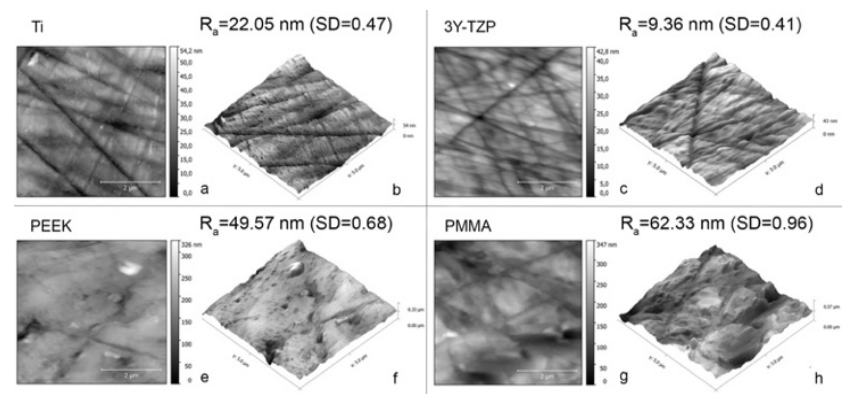

Fig. 2. 2D (a, c, e, g) and 3D (b, d, f, h) surface scans, and roughness means with standard deviations (SD) of samples ( $\mathrm{n}=10$ for each group): Ti, 3Y-TZP, PEEK and PMMA. Multiple comparisons by Tukey's test and significant difference among all groups at level $p<0.0001$

The qualitative analysis revealed that the polished surfaces of polymeric materials appeared to be nonhomogeneous (Fig. 2). Moreover, the difference in altitude for PEEK and PMMA was higher. Both of them had similar changes in the Z-axis: PEEK $-0.33 \mu \mathrm{m}$ and PMMA-0.37 $\mu \mathrm{m}$. However, the $\mathrm{Z}$-axis for $\mathrm{Ti}$ was $0.54 \mathrm{~nm}$, and it was $0.43 \mathrm{~nm}$ for 3Y-TZP. Deeper and sharper grooves and scratches, as well as left prominences, were detected on the polished polymeric materials. No melting signs were detected on surfaces.

\subsection{Bacterial growth}

The qualitative bacteriological verification confirmed $P$. Gingivalis colonies in all groups. Following quantitative results, the highest formation of colonies was assessed on the PMMA, and it was significantly different from other groups $(p<0.0001)$ (Fig. 3$)$. The CFUs $/ \mathrm{mL}$ mean was $3.27 \cdot 10^{8}$. The lowest CFUs/mL mean was on the 3Y-TZP, but no significant differences between Ti, 3Y-TZP and PEEK were detected.

Based on non-parametric Spearman correlation, linear regression showed that the growth of CFUs/mL increased with increasing surface roughness $(R=0.5554)$ (Fig. 4$)$. The significance level between $\mathrm{CFUs} / \mathrm{mL}$ vs. roughness was $p<0.0001$. The influence of WCA and SFE on the growth of CFUs/mL was not confirmed in this study. 


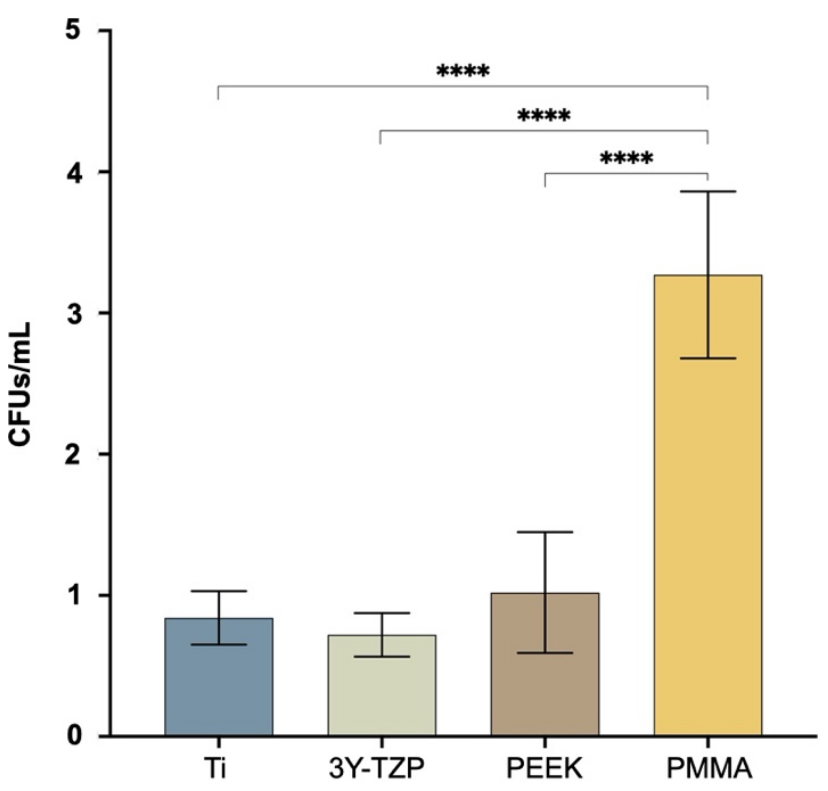

Fig. 3. CFUs $/ \mathrm{mL}$ of $P$. Gingivalis on polished surfaces of abutment materials ( $\mathrm{n}=10$ for each group): Ti, 3Y-TZP, PEEK and PMMA. Multiple comparisons by Tukey's test and significant difference at levels: ns $-p>0.05$ (nonmarked groups), $* * * *-p<0.0001$

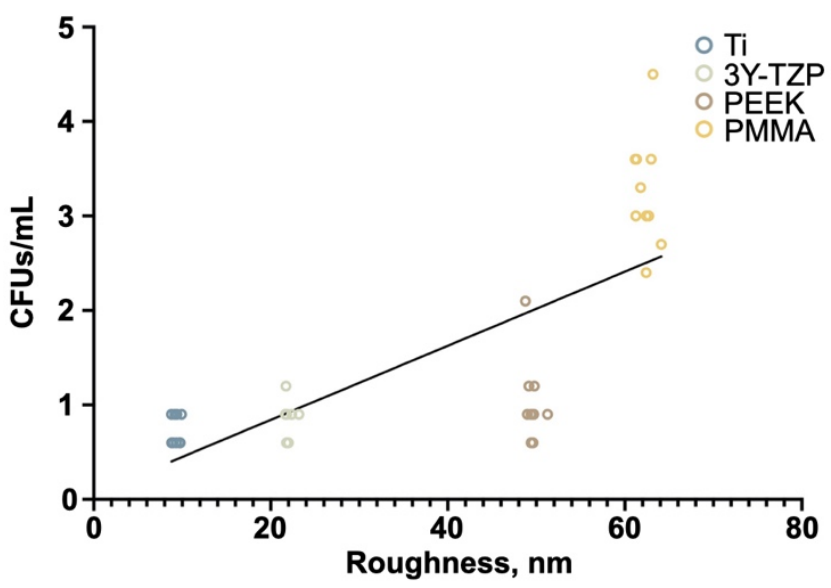

Fig. 4. Non-parametric Spearman correlation between CFUs/mL of $P$. Gingivalis and roughness of surfaces, and linear regression: $p<0.0001, R=0.5554$

\section{DISCUSSION}

To prevent biofilm attachment, it is necessary to improve the surface properties of abutments [36, 37]. It is important to ensure biocompatibility for soft tissues as well as to be antibacterial and limit the formation of biofilm. In this way, the traditional method of surface improvement is to perform polishing $[37,38]$, which was applied in this study.

According to the results of this study, the suggested novel polishing protocol with extended sequencing polishing resulted in especially low roughness of the abutment materials. The linear correlation between $R_{\mathrm{a}}$ and CFUs/ml revealed that this surface improvement decreased bacteria formation.

This study was conducted evaluating surface physicochemical properties of abutment materials as WCA, SFE and roughness. The WCA parameter reveals hydrophilicity/hydrophobicity rate, which might influence surface attraction for bacteria [39, 40]. Also, the performed systematic review revealed that SFE and roughness of transmucosal prosthetic parts are mainly related to the biofilm formation [16]. The higher SFE is more favorable for bacteria [41, 42] and roughness of the surface increase biofilm adhesion $[37,40]$.

In theory, the TI should exhibit much lower WCA and higher SFE due to the oxide layer that instantly forms at room temperature compared with our data [43]. However, hydrocarbons or other molecules in the atmosphere might contaminate such surfaces too, resulting in higher hydrophobicity $[44,45]$. Other researchers also obtained similar WCA and SFE values of the titanium [43, 46].

Due to the chemical composition based on the polymeric chain, both PMMA and PEEK should exhibit a hydrophobic character. However, in this study, the WCA values of PEEK were the lowest compared with other substrates. The ceramic filler of the PEEK could influence this. It is possible that during the polishing procedure part, inorganic filler was uncovered, resulting in a decreased overall surface hydrophobicity.

The findings of this study did not confirm relations between the WCA and strain formation and coincided with the results of another study [47]. Otherwise, existing data from other published studies provide us with ambiguous results-that extra-hydrophilic and extra-hydrophobic surfaces were unfavorable for bacteria-whereas moderate wettability with a WCA of about 90 degrees is the most favorable for bacterial adhesion $[39,48]$. However, the findings of other studies established that the WCA was not as influential as the roughness of the surface [49].

With a higher SFE, the surface incorporates a higher quantity of active ions, and such a surface becomes much more favourable for biofilm formation [41]. In this study SFE measurements were very close to previously published data with similar origin groups [38]. The highest SFE was detected on the PEEK surface. These results could also be due to the hybrid composition, and the exposed filler may promote unique surface properties as the oxygen-containing compounds increase the SFE. Also, composite polymers demonstrated a more expressed polar part, which could lead to a higher biocompatibility.

Data on correlations between the increased SFE of the material and the growth of bacteria have been published [42]. Results of this study SFE measurements were very similar for all of the tested groups, but correlations between SFE and CFUs/mL did not exist. However, studies on the interaction between $P$. Gingivalis and the SFE of various materials must be developed more in the future.

To prevent bacterial adhesion, the roughness $\left(R_{\mathrm{a}}\right)$ must be less than $0.2 \mu \mathrm{m}$ [16], but also contrary studies showed that bacteria could accumulate on even a smoother surface [50]. However, the accumulation is directly related to the roughness [49,51]. All findings of this study on surface roughness were below the level of $0.2 \mu \mathrm{m}$, which was mentioned in previous studies [16], and the surface smoothness was higher compared with other findings [52]. The same surface polishing changed the surface roughness differently of different materials, and it could be associated with the origin of the materials. It proves the possibility to 
achieve the nano-level of a glossy surface only by applying the sequential mechanical polishing of prosthetic materials. Moreover, the high smoothness of surfaces may also influence the previously mentioned surface properties, such as the WCA and SFE.

Changes in surface roughness affect the growth of bacteria on it. The linear regression was detected between the increment of surface roughness on the investigated prosthetic materials and the growth of $P$. Gingivalis $(R=0.5554)$. Also, a positive correlation between subgingival plaque retention and the roughness of the surface was established via in vivo findings $[53,54]$. The results of this study showed that CFUs/mL of $P$. Gingivalis on the PMMA was higher than on other prosthetic materials, and inorganic materials, such as Ti and $3 \mathrm{Y}-\mathrm{TZP}$, as well as PEEK, which were less attractive to P. Gingivalis. Different materials showed different surface roughness after polishing, and bacterial growth depended on the roughness. The results of this study revealed an especially low surface roughness of titanium and zirconium oxide compare to other studies $[33,55]$. From the clinical point of view, the choice of accurately polished titanium or zirconium could be promising surface at the gingival level. The relevance of surface treatment was established in other studies with gingival fibroblasts [56].

The findings of this study provide a valuable information for following in vivo and clinical studies. The late colonizer P. Gingivalis was used for this study as the main pathogen of peri-implant disease [57]. Also, the results of this study correlate with the results of the systematic review, which concluded that the majority of the studies $(78.9 \%)$ found that surface roughness (with varying degrees of roughness) influenced the bacterial biofilm attachment [58]. Still, the limitation of this study exists because of the monoculture biofilm model. Otherwise, this model is widespread for in vitro models, because of reliable implementation under anaerobic conditions [50].

\section{CONCLUSIONS}

The surface roughness was detected as a critical role factor, influencing the growth of bacteria, and fewer CFUs/mL of $P$. Gingivalis was detected on smoother surfaces versus rough surfaces. The highest CFUs/mL of P. Gingivalis was assessed on PMMA and was significantly different from others, whereas the lowest was on 3Y-TZP. This study confirmed the relation between changes in surface roughness and CFUs/mL, while other investigated surface physicochemical properties did not. Further studies are needed to investigate surface physicochemical properties of prosthetic materials on the biofilm formation in vivo and their influence on clinical outcomes.

\section{Acknowledgments}

The authors thank prof. Astra Vitkauskiene for advice and access to the Microbiological Research Laboratory of Lithuanian University of Health Sciences.

\section{REFERENCES}

1. Buser, D., Schenk, R.K., Steinemann, S., Fiorellini, J.P., Fox, C.H., Stich, H. Influence of Surface Characteristics on Bone Integration of Titanium Implants. A Histomorphometric Study in Miniature Pigs Journal of Biomedical Materials Research Part B: Applied Biomaterials 25 (7) 1991: pp. 889-902. https://doi.org/10.1002/jbm.820250708

2. Schenk, R.K., Buser, D. Osseointegration: a Reality Periodontology 200017 1998: pp. 22-35. https://doi.org/10.1111/j.1600-0757.1998.tb00120.x

3. Zhao, G., Raines, A.L., Wieland, M., Schwartz, Z., Boyan, B.D. Requirement for Both Micron- and Submicron Scale Structure for Synergistic Responses of Osteoblasts to Substrate Surface Energy and Topography Biomaterials 28 (18) 2007: pp. $2821-2829$.

https://doi.org/10.1016/j.biomaterials.2007.02.024

4. Rong, M., Lu, H., Wan, L., Zhang, X., Lin, X., Li, S., Zhou, L., Lv, Y., Su, Y. Comparison of Early Osseointegration Between Laser-treated/Acid-etched and Sandblasted/Acid-etched Titanium Implant Surfaces Journal of Materials Science: Materials in Medicine 29 (4) 2018: pp. $43-48$.

https://doi.org/10.1007/s10856-018-6049-1

5. Daudt, N.F., Bram, M., Barbosa, A.P.C., Jr, C.A. Surface Modification of Highly Porous Titanium by Plasma Treatment Materials Letters 141 2015: pp. 194-197. https://doi.org/10.1016/j.matlet.2014.11.083

6. Allegrini, S., Yoshimoto, M., Salles, M.B., de Almeda Bressiani, A.H.. Biologic Response to Titanium Implants with Laser-treated Surfaces The International Journal of Oral \& Maxillofacial Implants $29(1)$ 2014: pp. 63-70.

https://doi.org/10.11607/jomi.3213

7. Zhao, B., Mei, H.C., van der Subbiahdoss, G., Vries, J., de Rustema-Abbing, M., Kuijer, R., $\quad$ Busscher, H.J., Ren, Y. Soft Tissue Integration versus Early Biofilm Formation on Different Dental Implant Materials Dental Materials: Official Publication of the Academy of Dental Materials 30 (7) 2014: pp. 716-727. https://doi.org/10.1016/j.dental.2014.04.001

8. Dewhirst, F.E., Chen, T., Izard, J, Paster, B.J., Tanner, A.C.R., Yu, W.-H., Lakshmanan, A., Wade, W.G. The Human Oral Microbiome Journal of Bacteriology 2010: pp. 5002-5017.

https://doi.org/10.1128/JB.00542-10

9. Welander, M., Abrahamsson, I., Berglundh, T. The Mucosal Barrier at Implant Abutments of Different Materials Clinical Oral Implants Research 19 (7) 2008: pp. 635-641. https://doi.org/10.1111/j.1600-0501.2008.01543.x

10. Atsuta, I., Ayukawa, Y., Kondo, R., Oshiro, W., Matsuura, Y., Furuhashi, A., Tsukiyama, Y., Koyano, K. Soft Tissue Sealing Around Dental Implants Based on Histological Interpretation Journal of Prosthodontic Research 60 (1) 2016: pp. 3-11. https://doi.org/10.1016/j.jpor.2015.07.001

11. Brunot, C., Grosgogeat, B., Picart, C., $\quad$ Lagneau, C., Jaffrezic-Renault, N., Ponsonnet, L. Response of Fibroblast Activity and Polyelectrolyte Multilayer Films Coating Titanium Dental Materials 24 (8) 2008: pp. $1025-1035$. https://doi.org/10.1016/j.dental.2007.11.022

12. Brunot-Gohin, C., $\quad$ Duval, J.L., $\quad$ Azogui, E.E., Jannetta, R., $\quad$ Pezron, I., $\quad$ Laurent-Maquin, D., 
Gangloff, S.C., Egles, C. Soft Tissue Adhesion of Polished versus Glazed Lithium Disilicate Ceramic for Dental Applications Dental Materials: Official Publication of the Academy of Dental Materials 29 (9) 2013: pp. e205-12. https://doi.org/10.1016/j.dental.2013.05.004

13. Mehl, C., Kern, M., Schütte, A.M., Kadem, L.F., Selhuber-Unkel, C. Adhesion of Living Cells to Abutment Materials, Dentin, and Adhesive Luting Cement with Different Surface Qualities Dental Materials: Official Publication of the Academy of Dental Materials 32 (12) 2016: pp. 1524-1535.

https://doi.org/10.1016/j.dental.2016.09.006

14. de Avila, E.D., de Molon, R.S., Spolidorio, D.P.M., de Assis Mollo, F.J. Implications of Surface and Bulk Properties of Abutment Implants and Their Degradation in the Health of Periodontal Tissue Materials 6 (12) 2013: pp. $5951-5966$.

https://doi.org/10.3390/ma6125951

15. de Avila, E.D., de Molon, R.S., Vergani, C.E., de Assis Mollo, F.J., Salih, V. The Relationship between Biofilm and Physical-Chemical Properties of Implant Abutment Materials for Successful Dental Implants Materials 7 (5) 2014: pp. 3651-3662. https://doi.org/10.3390/ma7053651

16. Teughels, W., Assche, N.V., Sliepen, I., Quirynen, M. Effect of Material Characteristics and/or Surface Topography on Biofilm Development Clinical Oral Implants Research 17 (S2) 2006: pp. 68-81. https://doi.org/10.1111/j.1600-0501.2006.01353.x

17. de Avila, E.D., Avila-Campos, M.J., Vergani, C.E., Spolidorio, D.M.P., de Assis Mollo, F.J. Structural and Quantitative Analysis of a Mature Anaerobic Biofilm on Different Implant Abutment Surfaces The Journal of Prosthetic Dentistry 115 (4) 2016: pp. 428-436. https://doi.org/10.1016/j.prosdent.2015.09.016

18. Merdji, A., Della, N., Benaissa, A., Bouiadjra, B.A.B., Serier, B., Mootanah, R., Muslih, I., Mukdadi, O.M. Numerical Analysis of Dental Caries Effect on the Biomechanical Behavior of the Periodontal System Journal of Nanotechnology in Engineering and Medicine 6(3) 2015: pp. $1264-1293$.

https://doi.org/10.1115/1.4032689

19. Kasani, R., Attili, B.K.R.S., Dommeti, V.K., Merdji, A., Biswas, J., Roy, S. Stress Distribution of Overdenture Using Odd Number Implants - A Finite Element Study Journal of the Mechanical Behavior of Biomedical Materials 98 2019: pp. 369-382.

https://doi.org/10.1016/j.jmbbm.2019.06.030

20. Maminskas, J., Puisys, A., Kuoppala, R., Raustia, A., Juodzbalys, G. The Prosthetic Influence and Biomechanics on Peri-Implant Strain: a Systematic Literature Review of Finite Element Studies Journal of Oral \& Maxillofacial Research 7 (3) 2016: pp. e4. https://doi.org/10.5037/jomr.2016.7304

21. Drai, A., Merdji, A., Albedah, A., Bouiadjra, B.A.B., Benyahia, F., Mohammed, S.M. Effect of Dental Implantology on the Biomechanical Behavior of Alveolar Bone International Journal for Multiscale Computational Engineering 16 (6) 2018: pp. 579-593. https://doi.org/10.1615/intjmultcompeng.2018028717

22. Heitz-Mayfield, L.J.A., Salvi, G.E. Peri-implant Mucositis Journal of Clinical Periodontology 45 (20) 2018: pp. S237-S245.

https://doi.org/10.1111/jcpe.12953
23. Lang, N.P., Berglundh, T. Periimplant Diseases: Where Are We Now? Consensus of the Seventh European Workshop on Periodontology, 2011: pp. 178-181. https://doi.org/10.1111/j.1600-051x.2010.01674.x

24. Renvert, S., Polyzois, I. Risk Indicators for Peri-implant Mucositis: a Systematic Literature Review Journal of Clinical Periodontology 42 (16) 2015: pp. S172-86. https://doi.org/10.1111/jcpe.12346

25. Schincaglia, G.P., Hong, B.Y., Rosania, A., Barasz, J., Thompson, A., Sobue, T., Panagakos, F., Burleson, J.A., Dongari-Bagtzoglou, A., Diaz, P.I. Clinical, Immune, and Microbiome Traits of Gingivitis and Peri-implant Mucositis Journal of Dental Research 96 (1) 2017: pp. 47-55. https://doi.org/10.1177/0022034516668847

26. Jepsen, S., $\quad$ Berglundh, T., Genco, R., $\quad$ Aass, A.M., Demirel, K., Derks, J., Figuero, E., Giovannoli, J.L., Goldstein, M., Lambert, F., Ortiz-Vigon, A., Polyzois, I., Salvi, G.E., $\quad$ Schwarz, F., $\quad$ Serino, G., $\quad$ Tomasi, C., Zitzmann, N.U. Primary Prevention of Peri-implantitis: Managing Peri-implant Mucositis Journal of Clinical Periodontology 42 (16) 2015: pp. S152-7.

https://doi.org/10.1111/jcpe.12369

27. Holt, S.C., Kesavalu, L., Walker, S., Genco, C.A. Virulence Factors of Porphyromonas Gingivalis Periodontology 200020 (1) 1999: pp. 168-238. https://doi.org/10.1111/j.1600-0757.1999.tb00162.x

28. Shibli, J.A., Melo, L., Ferrari, D.S., Figueiredo, L.C., Faveri, M., Feres, M. Composition of Supra- and Subgingival Biofilm of Subjects with Healthy and Diseased Implants Clinical Oral Implants Research $19(10)$ 2008: pp. $975-982$.

https://doi.org/10.1111/j.1600-0501.2008.01566.x

29. Stephen, A.S., Millhouse, E., Sherry, L., AduseOpoku, J., Culshaw, S., Ramage, G., Bradshaw, D.J., Burnett, G.R., Allaker, R.P. In Vitro Effect of Porphyromonas gingivalis Methionine Gamma Lyase on Biofilm Composition and Oral Inflammatory Response Plos One 11 (12) 2016: pp. e0169157. https://doi.org/10.1371/journal.pone.0169157

30. Singhrao, S.K., Olsen, I. Assessing the Role of Porphyromonas Gingivalis in Periodontitis to Determine a Causative Relationship with Alzheimer's Disease Journal of Oral Microbiology 11 (1) 2019: pp. 1563405. https://doi.org/10.1080/20002297.2018.1563405

31. Kurahashi, K., Matsuda, T., Ishida, Y., Ichikawa, T. Effect of Polishing Protocols on the Surface Roughness of Polyetheretherketone Journal of Oral Science 62 (1) 2020: pp. $40-42$. https://doi.org/10.2334/josnusd.18-0473

32. Ferraris, S., Warchomicka, F., Ramskogler, C., Tortello, M., Cochis, A., Scalia, A., Confiengo, G.G., di Keckes, J., Rimondini, L., Spriano, S. Surface Structuring by Electron Beam for Improved Soft Tissues Adhesion and Reduced Bacterial Contamination on Ti-grade 2 Journal of Materials Processing Technology. 266 2019: pp. 518-529. https://doi.org/10.1016/j.jmatprotec.2018.11.026

33. Linkevicius, T., $\quad$ Valantiejiene, V., $\quad$ Alkimavicius, J., Gineviciute, E., Andrijauskas, R., Linkeviciene, L. The Effect of a Polishing Protocol on the Surface Roughness of Zirconium Oxide The International Journal of Prosthodontics 33 (2) 2020: pp. 217-223. https://doi.org/10.11607/ijp.6686

34. Standardization I.O. for ISO Catalogue, 1997. 
35. Owens, D.K., Wendt, R.C. Estimation of the Surface Free Energy of Polymers Journal of Applied Polymer Science 13 (8) 1969: pp. $1741-1747$. https://doi.org/10.1002/app.1969.070130815

36. Zhao, L., Chu, P.K., Zhang, Y., Wu, Z. Antibacterial Coatings on Titanium Implants Journal of Biomedical Materials Research Part B: Applied Biomaterials 91 (1) 2009: pp. $470-480$.

https://doi.org/10.1002/jbm.b.31463

37. Ferraris, S., Giachet, F.T., Miola, M., Bertone, E., Varesano, A., Vineis, C., Cochis, A., Sorrentino, R., Rimondini, L., Spriano, S. Nanogrooves and Keratin Nanofibers on Titanium Surfaces Aimed at Driving Gingival Fibroblasts Alignment and Proliferation without Increasing Bacterial Adhesion Materials Science \& Engineering. C, Materials for Biological Applications 76 2017: pp. 1-12. https://doi.org/10.1016/j.msec.2017.02.152

38. Hahnel, S., Wieser, A., Lang, R., Rosentritt, M. Biofilm Formation on the Surface of Modern Implant Abutment Materials Clinical Oral Implants Research 26 (11) 2015: pp. $1297-1301$.

https://doi.org/10.1111/clr.12454

39. Yuan, Y., Hays, M.P., Hardwidge, P.R., Kim, J. Surface Characteristics Influencing Bacterial Adhesion to Polymeric Substrates RSC Advances 7 (23) 2017: pp. 14254-14261. https://doi.org/10.1039/c7ra01571b

40. Jian, X., Huang, W., Wu, D., You, D., Lin, Z., Chen, J. Effect of Fibronectin-Coated Micro-Grooved Titanium Surface on Alignment, Adhesion, and Proliferation of Human Gingival Fibroblasts Medical Science Monitor 23 2017: pp. 4749-4759. https://doi.org/10.12659/msm.903883

41. Mabboux, F., Ponsonnet, L., Morrier, J.J., Jaffrezic, N., Barsotti, O. Surface Free Energy and Bacterial Retention to Saliva-coated Dental Implant Materials--an in vitro Study Colloids and Surfaces. B, Biointerfaces 39 (4) 2004: pp. 199-205.

https://doi.org/10.1016/j.colsurfb.2004.08.002

42. Pereni, C.I., Zhao, Q., Liu, Y., Abel, E. Surface Free Energy Effect on Bacterial Retention Colloids and Surfaces. B, Biointerfaces 48 (2) 2006: pp. 143-147. https://doi.org/10.1016/j.colsurfb.2006.02.004

43. Kilpadi, D.V., Lemons, J.E. Surface Energy Characterization of Unalloyed Titanium Implants Journal of Biomedical Materials Research Part B: Applied Biomaterials 28 (12) 1994: pp. 1419-1425. https://doi.org/10.1002/jbm.820281206

44. Han, A., Tsoi, J.K.H., Matinlinna, J.P., Zhang, Y., Chen, Z. Effects of Different Sterilization Methods on Surface Characteristics and Biofilm Formation on Zirconia in Vitro Dental Materials: Official Publication of the Academy of Dental Materials 34 (2) 2018: pp. 272-281. https://doi.org/10.1016/j.dental.2017.11.012

45. Kummer, K.M., Taylor, E.N., $\quad$ Durmas, N.G., Tarquinio, K.M., Ercan, B., Webster, T.J. Effects of Different Sterilization Techniques and Varying Anodized $\mathrm{TiO}_{2}$ Nanotube Dimensions on Bacteria Growth Journal of Biomedical Materials Research Part B: Applied Biomaterials 101 (5) 2013: pp. 677-688. https://doi.org/10.1002/jbm.b.32870

46. Rosales-Leal, J.I., Rodríguez-Valverde, M.A., Mazzaglia, G., $\quad$ Ramón-Torregrosa, P.J., $\quad$ DíazRodríguez, L., García-Martínez, O., VallecilloCapilla, M., Ruiz, C., Cabrerizo-Vílchez, M.A. Effect of
Roughness, Wettability and Morphology of Engineered Titanium Surfaces on Osteoblast-like Cell Adhesion Colloids and Surfaces A: Physicochemical and Engineering Aspects $365(1-3)$ 2010: pp. 222-229.

https://doi.org/10.1016/j.colsurfa.2009.12.017

47. Lorenzetti, M., Dogša, I., Stošicki, T., Stopar, D., Kalin, M., Kobe, S., Novak, S. The Influence of Surface Modification on Bacterial Adhesion to Titanium-based Substrates ACS Applied Materials \& Interfaces 7 (3) 2015: pp. $1644-1651$. https://doi.org/10.1021/am507148n

48. Stallard, C.P., $\quad$ McDonnell, K.A., $\quad$ Onayemi, O.D., O'Gara, J.P., Dowling, D.P. Evaluation of Protein Adsorption on Atmospheric Plasma Deposited Coatings Exhibiting Superhydrophilic to Superhydrophobic Properties Biointerphases 7 (1-4) 2012: pp. 31-42. https://doi.org/10.1007/s13758-012-0031-0

49. Almaguer-Flores, A., Olivares-Navarrete, R., Wieland, M., Ximénez-Fyvie, L.A., Schwartz, Z., Boyan, B.D. Influence of Topography and Hydrophilicity on Initial Oral Biofilm Formation on Microstructured Titanium Surfaces in Vitro Clinical Oral Implants Research 23 (3) 2012: pp. 301-307. https://doi.org/10.1111/j.1600-0501.2011.02184.x

50. Amoroso, P.F., $\quad$ Pier-Francesco, A., $\quad$ Adams, R.J., Waters, M.G.J., Williams, D.W. Titanium Surface Modification and Its Effect on the Adherence of Porphyromonas Gingivalis: an in Vitro Study Clinical Oral Implants Research 17 (6) 2006: pp. 633-637. https://doi.org/10.1111/j.1600-0501.2006.01274.x

51. Hahnel, S., Wastl, D.S., $\quad$ Schneider-Feyrer, S., Giessibl, F.J., Brambilla, E., Cazzaniga, G., Ionescu, A. Streptococcus Mutans Biofilm Formation and Release of Fluoride from Experimental Resin-based Composites Depending on Surface Treatment and S-PRG Filler Particle Fraction The Journal of Adhesive Dentistry 16 (4) 2014: pp. 313-321. https://doi.org/10.3290/j.jad.a31800

52. de Avila, E.D., de Molon, R.S., Lima, B.P., Lux, R., Shi, W., $\quad$ Jafelicci, M.J., $\quad$ Spolidorio, D.M.P., Vergani, C.E., de Assis Mollo, F.J. Impact of Physical Chemical Characteristics of Abutment Implant Surfaces on Bacteria Adhesion The Journal of Oral Implantology 42 (2) 2016: pp. 153-158.

https://doi.org/10.1563/aaid-joi-d-14-00318

53. Schwarz, F., Sculean, A., Wieland, M., Horn, N., Nuesry, E., Bube, C., Becker, J. Effects of Hydrophilicity and Microtopography of Titanium Implant Surfaces on Initial Supragingival Plaque Biofilm Formation. A Pilot Study Mund Kiefer Gesichtschirurgie: MKG $11(6)$ 2007: pp. 333-338.

https://doi.org/10.1007/s10006-007-0079-z

54. Schwarz, F., Ferrari, D., Herten, M., Mihatovic, I., Wieland, M., Sager, M., Becker, J. Effects of Surface Hydrophilicity and Microtopography on Early Stages of Soft and Hard Tissue Integration at Non-submerged Titanium Implants: an Immunohistochemical Study in Dogs Journal of Periodontology 78 (11) 2007: pp. 2171-2184. https://doi.org/10.1902/jop.2007.070157

55. Fischer, N.G., Wong, J., Baruth, A., Cerutis, D.R. Effect of Clinically Relevant CAD/CAM Zirconia Polishing on Gingival Fibroblast Proliferation and Focal Adhesions Materials 10 (12) 2017: pp. 1358-1373. https://doi.org/10.3390/ma10121358

56. Maminskas, J., Pilipavicius, J., $\quad$ Staisiunas, E., Baranovas, G., Alksne, M., Daugela, P., Juodzbalys, G. 
Novel Yttria-Stabilized Zirconium Oxide and Lithium Disilicate Coatings on Titanium Alloy Substrate for Implant Abutments and Biomedical Application Materials 13 (9) 2020: pp. $2070-2088$.

https://doi.org/10.3390/ma13092070

57. How, K.Y., Song, K.P., Chan, K.G. Porphyromonas gingivalis: An Overview of Periodontopathic Pathogen below the Gum Line Frontiers in Microbiology 7 (258) 2016: pp. 5721-5733. https://doi.org/10.3389/fmicb.2016.00053

58. Dhaliwal, J.S., Rahman, N.A., Knights, J., Ghani, H., de Albuquerque, R.F.J. The Effect of Different Surface Topographies of Titanium Implants on Bacterial Biofilm: a Systematic Review SN Applied Sciences $1(6)$ 2019: pp. $1139-1154$. https://doi.org/10.1007/s42452-019-0638-6

(c) Maminskas et al. 2021 Open Access This article is distributed under the terms of the Creative Commons Attribution 4.0 International License (http://creativecommons.org/licenses/by/4.0/), which permits unrestricted use, distribution, and reproduction in any medium, provided you give appropriate credit to the original author(s) and the source, provide a link to the Creative Commons license, and indicate if changes were made. 